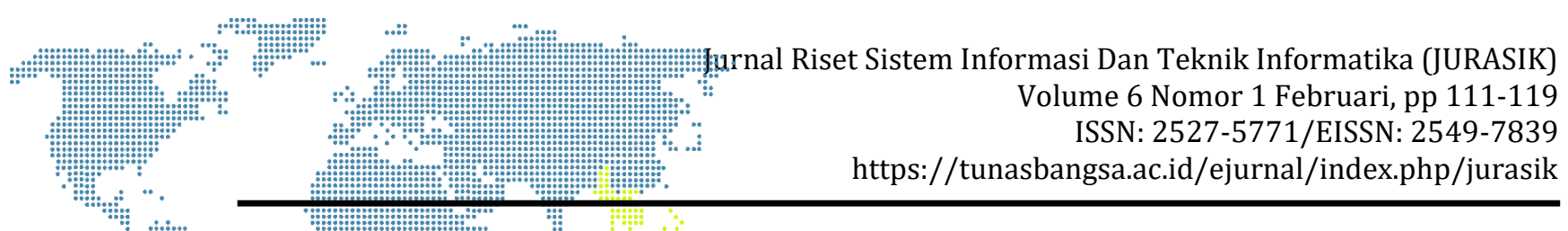

\title{
Analisis Penjualan Produk Paket Kuota Internet Dengan Metode K-Nearest Neighbor
}

\author{
Dedi Handoko' ${ }^{1}$, Heru Satria Tambunan ${ }^{2}$, Jaya Tata Hardinata ${ }^{3}$ \\ ${ }^{1}$ Mahasiswa STIKOM Tunas Bangsa, Pematangsiantar, Sumatera Utara, Indonesia \\ 2,35TIKOM Tunas Bangsa, Pematangsiantar, Sumatera Utara, Indonesia \\ Jln. Sudirman Blok A No. 1-3 Pematangsiantar, Sumatera Utara \\ 1alndedihandoko@gmail.com, ${ }^{2}$ heru@amiktunasbangsa.ac.id
}

\begin{abstract}
PT. Akses Lintas Nusantara is a company engaged in the sale of Internet Quota Packages and package balances. This company has various data packages ranging from 6 GB, 11 GB, 21 GB and 32 $G B$ with various price variations. Based on data on sales of internet quota package products for the past 1 (one) year, predictions for future sales are needed in order to facilitate the company in planning the provision of internet quota package stock. The K-Nearest Neighbor (KNN) algorithm is a method that is a supervised algorithm where the results of the new test sample are classified based on the majority of the categories on the KNN. To find out the sales of these products, the K-Nearest Neighbor algorithm is used. The expected result is to make it easier for companies to predict the future supply of internet quota packages in each region or region. The results of the research that have been carried out are prediction of Internet Quota Package Sales consisting of SP CL1, SPCL2, SPCL4 and SP CL8 with an Accuracy of $71.43 \%$.
\end{abstract}

Keywords: Sales, Data Mining Quota Package, Prediction, $k$-nearest neighbor

\section{Abstrak}

PT. Akses Lintas Nusantara adalah Perusahaan yang bergerak di bidang Penjualan Paket Kuota Internet dan saldo paket. Perusahaan ini memiliki berbagai paket data mulai dari 6 GB, 11 GB, 21 GB dan 32 GB dengan berbagai variasi harga. Berdasarkan data penjualan produk paket kuota internet selama 1(satu) tahun terakhir, maka dibutuhkan prediksi untuk penjualan kedepannya guna untuk mempermudah pihak perusahaan dalam perencanaan penyediaan stok paket kuota internet. Algoritma K-Nearest Neighbor (KNN) adalah suatu metode yang merupakan algoritma supervised dimana hasil dari Sampel uji yang baru diklasifikasikan berdasarkan mayoritas dari kategori pada KNN. Untuk mengetahui penjualan produk tersebut digunakan algoritma K-Nearest Neighbor. Hasil yang diharapkan adalah mempermudah perusahaan memprediksi penyediaan stok paket kuota internet ke depannya di setiap daerah atau wilayah. Hasil dari Penelitian yang telah di lakukan Prediksi Penjualan Paket Kuota Internet terdiri dari SP CL1, SPCL2, SPCL4 dan SP CL8 dengan Accuracy sebesar $71,43 \%$.

Kata kunci: Penjualan, Paket Kuota Data Mining, Prediksi, k-nearest neighbor

\section{PENDAHULUAN}

Perkembangan yang sangat pesat dalam Perkembangan bidang teknologi sekarang ini membuat banyak peluang usaha, salah satunya dibidang penjualan paket kuota internet. Paket kuota internet sangat berkaitan erat dengan telepon selular yang merupakan suatu kebutuhan pokok manusia saat ini, sehingga bisnis yang berkaitan dengan penjualan kartu perdana internet merupakan bisnis yang memiliki prospek yang sangat baik. Paket kuota internet digunakan untuk mendukung penggunaan telepon selular dalam pencarian berbagai informasi dan lain-lain melalui media online. Salah satunya di sebuah perusahaan yang bernama PT. Akses Lintas Nusantara (Dealer Authorized). 


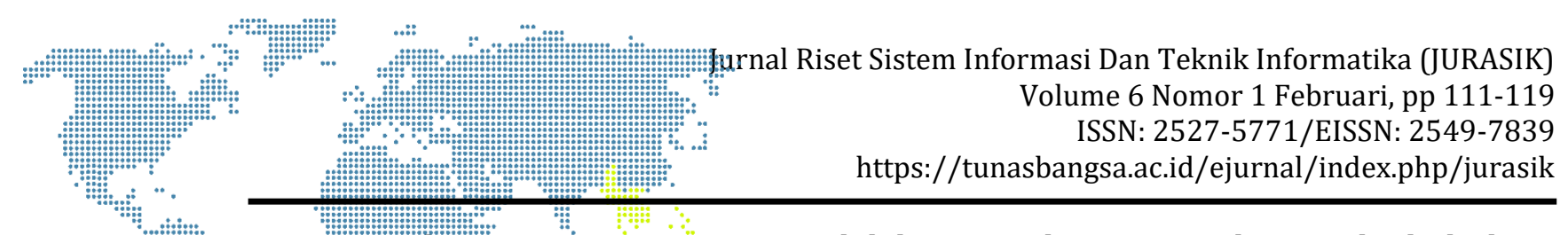

PT. Aleses Lintas Nusantara adalah Perusahaan yang bergerak di bidang Penjualan Paket Kuota Internet dan saldo paket. Perusahaan ini memiliki berbagai produk palket kuota interitet nulài dari 4,5 GB, 8 GB, 15 GB dan 21 GB dengan berbagai variasi harga. Berdasarkan data penjualan produk paket kuota internet selama 1(satu) tahun terakhir, PT. Akses Lintas Nusantara belum mampu memprediksi penjualan paket kuota internet sehingga terjual hanya beberapa saja maka dibutuhkan prediksi untuk penjualan kedepannya guna untuk mempermudah pihak perusahaan dalam perencanaan penyediaan stok dan mengetahui penjualan produk paket kuota internet yang terlaris.

Untuk mengetahui prediksi penjualan paket kuota internet maka di butuhkan sebuah metode yang dapat memprediksi penjualan paket kuota internet pada PT. Akses Lintas Nusantara maka di butuhkan Metode K-Nearest Neighbor. K-Nearest Neighbor adalah sebuah metode klasifikasi terhadap sekumpulan data berdasarkan pembelajaran data yang sudah Terkumpul sebelumya. Termasuk dalam supervised learning, dimana hasil query instance yang baru diklasifikasikan berdasarkan mayoritas kedekatan jarak dari kategori.

Dari permasalahan di atas dalam memprediksi penjualan paket kuota internet untuk penyediaan stok barang dan mengetahui penjualan produk terlaris. Penelitian ini diharapkan dapat membantu dalam prediksi penjualan Paket Kuota Internet untuk kedepannya dan dalam penyediaan stok barang dengan menggunakan metode K-Nearest Neighbor Pada PT.Akses Lintas Nusantara Pematangsiantar lebih cepat dan muda untuk di ketahui.

\section{METODOLOGI PENELITIAN}

\subsection{Pengumpulan Data}

Dalam melakukan penelitian untuk mendapatkan data dan informasi, maka metode yang digunakan dalam proses pengumpulan data sebagai berikut:

1. Metode Observasi, melihat serta mempelajari permasalahan yang ada di lapangan yang berkaitan dengan objek yang diteliti.

2. Metode Kajian Literatur, mencari bahan yang mendukung dalam pendefinisian masalah melalui buku-buku, makalah, internet, yang erat kaitannya dengan objek permasalahan.

3. Data penelitian yang digunakan diperoleh langsung dari pihak PT.Akses Lintas Nusantara dari hasil observasi dan dengan memintak kebagian Adminstrasi logistik. Data penelitian yang digunakan diambil dari 3 tahun yaitu 2017 dan 2019. Data yang digunakan adalah data penjualan paket kuota internet dengan 4 jenis paket inetrnet yaitu SP WL CL1 GB / 3,5 GB / 4,5 GB, SP WL CL2 GB / 6 GB / 8 GB, SP WL CL4 GB / 11 GB /15 GB, SP WL CL8 21 GB.

Berikut adalah data penelitian yang digunakan. Data penelitian yang digunakan diperoleh langsung dari pihak PT.Akses Lintas Nusantara dari hasil observasi dan dengan memintak kebagian Adminstrasi logistik. 


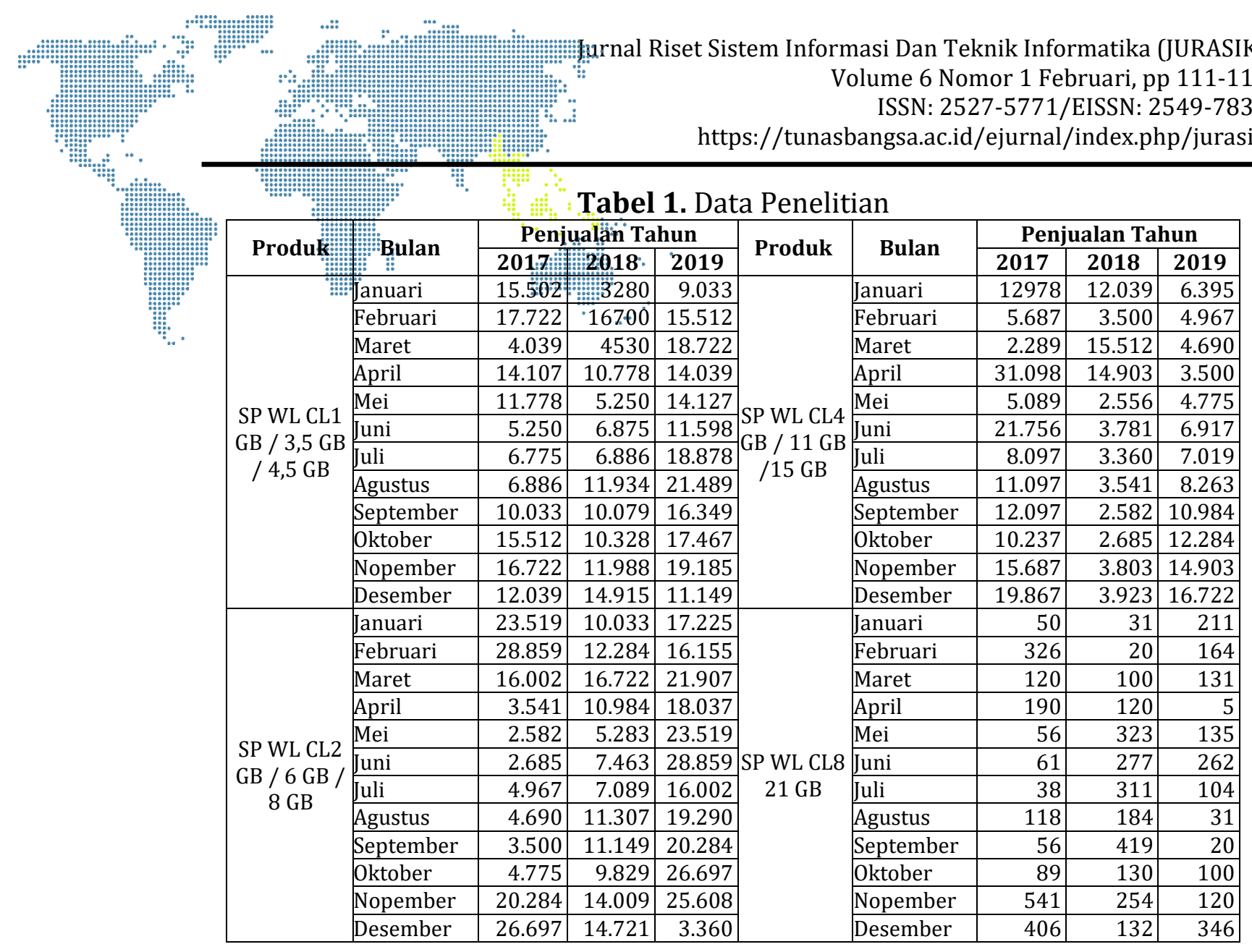

\subsection{Tahapan Penelitian}

Pada tahapan ini, peneliti mengindetifikasi penelitian yang akan dilakukan dengan melakukan studi pustaka. Hal ini bertujuan untuk mengetahui metode apa yang akan digunakan untuk menyelesaikan permasalahan yang akan diteliti, serta mendapat dasar-dasar referensi yang kuat dalam menerapkan suatu metode yang akan digunakan didalam skripsi ini. Dapat dilihat pada gambar 2 dibawah ini:

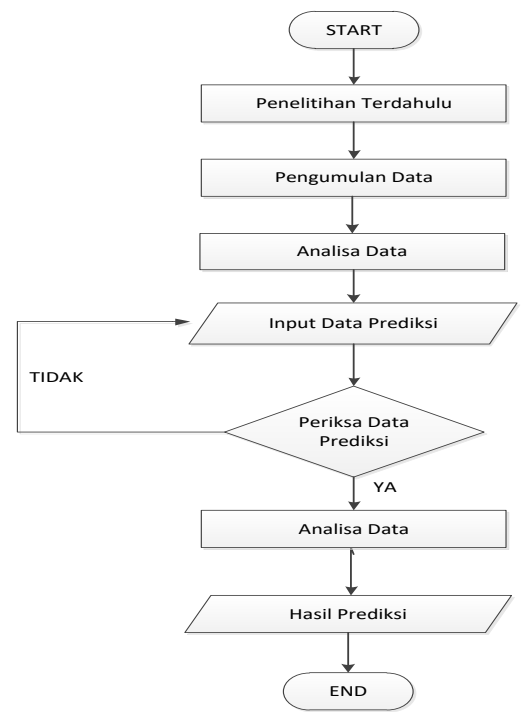

Gambar 1. Flowchart Tahapan Penelitian 


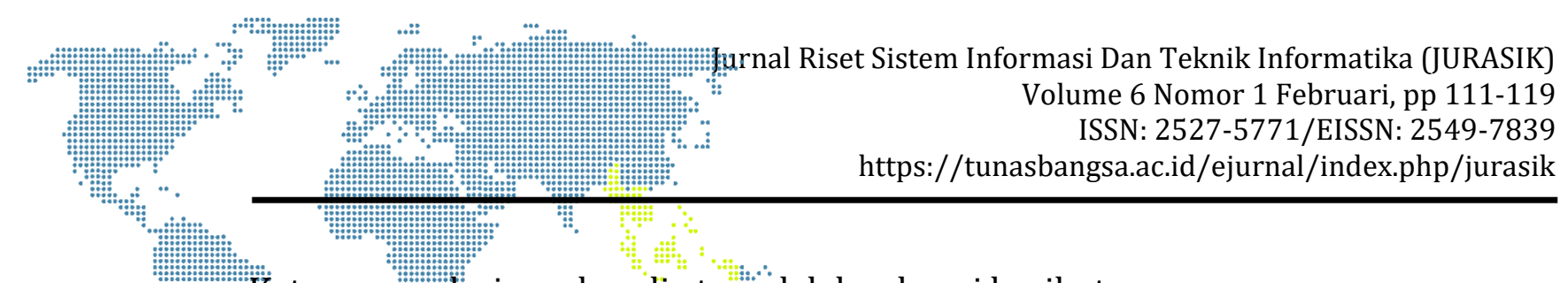

Keterangamo ara gambar di atas âdalah sebagai berikut :

1. Meneintakn penelitihän ter tahulu dan yang terkait

2. Proses pengumpulan datà yang akan di uji.

3. Proses analisa data yang akan di uji.

4. Melakukan input Data Yang akan di Prediksi

5. Periksa data yang akan di prediksi jika berhasil maka akan ke proses data Dengan Metode K-Nearest Neighbor jika Tidak Maka akan kembali ke Penginputan Data Prediksi

6. Proses data yang akan di olah dengan metode K-Nearest Neighbor.

7. Prediksi akan berhasil jika data tersebut akan falid.

\subsection{Metode Penelitian}

1) Data Mining

Menurut [1] Data mining adalah serangkai proses untuk menggali nilai tambahan berupa informasi yang selama ini tidak di ketahui secara manual dari suatu basis data. Informasi yang di hasilkan di peroleh dengan cara mengekstraksi dan mengenali pola yang penting atau menarik data yang terdapat pada basis data. Data mining terutama di gunakan untuk mencari pengetahuan yang terdapat pada basis data yang besar sehingga sering disebut. Knowledge Discovery Database (KDD)[2][3].

2) Metode K-Neraest Neighbor

K-Nearest Neighbor (KNN) adalah suatu metode yang menggunakan algoritma supervised dimana hasil query instance yang baru diklasifikasikan berdasarkan mayoritas dari label class pada K-NN. Tujuan dari algoritma ini adalah mengklasifikasikan objek baru berdasarkan atribut dan training data. Algoritma K-NN bekerja berdasarkan jarak terpendek dary query instance ke training data untuk menentukan K-NN-nya [4].

Algoritma K-Nearest Neighbor (KNN) adalah sebuah metode untuk melakukan klasifikasi terhadap objek berdasarkan data pembelajaran yang jaraknya paling dekat dengan objek tersebut. Teknik ini sangat sederhana dan mudah diimplementasikan[5]. Mirip dengan teknik clustering, yaitu mengelompokkan suatu data baru berdasarkan jarak data baru itu ke beberapa data/tetangga terdekat. Pertama sebelum mencari jarak data ke tetangga adalah menentukan nilai $\mathrm{K}$ tetangga (neighbor) [4]. Lalu, untuk mendefinisikan jarak antara dua titik yaitu titik pada data training dan titik pada data testing, maka digunakan rumus Euclidean dengan persamaan 1, sebagai berikut.

$d=(a, b)=\sum_{i=0}^{n}(x i-Y i) 2$

Keterangan:

$\mathrm{d}(\mathrm{a}, \mathrm{b})$ jarak Eclidian

$\mathrm{x} \quad$ : data 1

y : data 2

i : fitur ke -

n : jumlah Fitur 


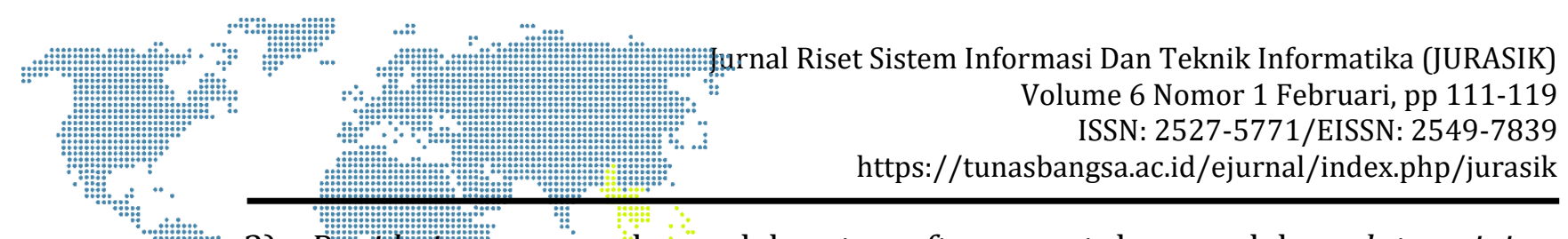

3) Rapidmimer merupakan salah satu software untuk pengolahan data mining. Pekejaan yang dilakukan oleh rapidminer text mining adalah berkisar dengan analisis: teks, meingetsstrak pola-pola dari dataset yang besar mengkombinasikannya dengan metode statistika,kecerdasan buatan dan database [6].

Aplikasi yang dibutuhkan oleh penulis untuk melakukan prediksi penjualan paket kuota internet adalah menggunakan aplikasi Rapidminer versi 5.3, berikut tampilan Rapidminer versi 5.3. terdapat pada gambar 2:

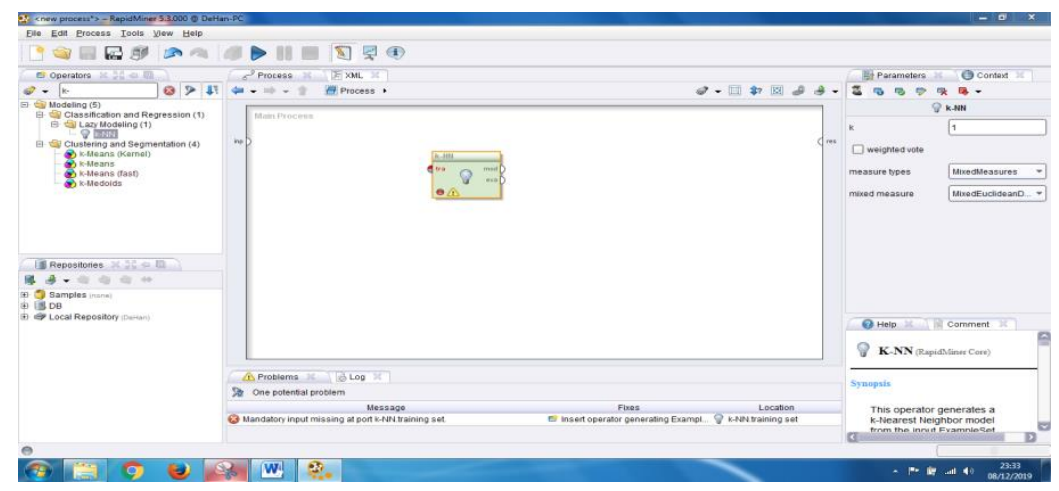

Gambar 2. Tampilan RapidMiner versi 5.3

\section{HASIL DAN PEMBAHASAN}

\subsection{Perhitungan Menggunakan Metode K-means}

Data yang digunakan adalah data penjualan paket kuota internet dengan 4 jenis paket internet. Data yang digunakan adalah data tahun 2017-2019. Adapun atribut yang digunakan dalam penelitian ini yaitu Nama Produk, Kuant, dan Bulan. Lalu dilakukan tahap preprocessing untu mengelompokkan penjualan produk berdasarkan jumlah penjualan tiap bulan dan tahunnya. Kemudian data yang digunakan diseleksi dan akan digunakan untuk diolah dalam memprediksi penjualan paket kuota internet XL. Berikut adalah data penjualan yang sudah dikonversi:

Tabel 2. Tabel Penilaian Alternatif

\begin{tabular}{|l|c|c|c|}
\hline Bulan & Tahun 2017 & Tahun 2018 & Tahun 2019 \\
\hline Januari & 9 & 6 & 7 \\
\hline Februari & 9 & 9 & 9 \\
\hline Maret & 6 & 6 & 9 \\
\hline April & 8 & 8 & 8 \\
\hline Mei & 8 & 7 & 8 \\
\hline Juni & 7 & 7 & 8 \\
\hline Juli & 7 & 7 & 9 \\
\hline Agustus & 7 & 8 & 9 \\
\hline September & 8 & 8 & 9 \\
\hline Oktober & 9 & 8 & 9 \\
\hline Nopember & 9 & 8 & 9 \\
\hline Desember & 8 & 8 & 7 \\
\hline
\end{tabular}


Selạmumeteya dilakukan taham transformation. Tahap teransformation adalah tähap menabentuk data menjadi data training dan data testing. Proses pembentukan "data training berdasarkan data yang ada, data harus di seleksi terlebih dahulu untuk menentukan atribut mna yang dapat mempengaruhi penjualan terlaris yang disebut data target. Adapun data traning yang digunakan sebagai berikut:

Tabel 3. Data Training Penjualan Kartu Paket SP1

\begin{tabular}{|c|c|c|c|c|c|c|}
\hline No & BL1 & BL2 & BL3 & BL4 & BL5 & TARGET \\
\hline 1 & 9 & 9 & 6 & 8 & 8 & 7 \\
\hline 2 & 9 & 6 & 8 & 8 & 7 & 7 \\
\hline 3 & 6 & 8 & 8 & 7 & 7 & 7 \\
\hline 4 & 8 & 8 & 7 & 7 & 7 & 8 \\
\hline 5 & 8 & 7 & 7 & 7 & 8 & 9 \\
\hline 6 & 7 & 7 & 7 & 8 & 9 & 9 \\
\hline 7 & 7 & 7 & 8 & 9 & 9 & 8 \\
\hline 8 & 7 & 8 & 9 & 9 & 8 & 6 \\
\hline 9 & 8 & 9 & 9 & 8 & 6 & 9 \\
\hline 10 & 9 & 9 & 8 & 6 & 9 & 6 \\
\hline 11 & 9 & 8 & 6 & 9 & 6 & 8 \\
\hline 12 & 8 & 6 & 9 & 6 & 8 & 7 \\
\hline 13 & 6 & 9 & 6 & 8 & 7 & 7 \\
\hline 14 & 9 & 6 & 8 & 7 & 7 & 7 \\
\hline 15 & 6 & 8 & 7 & 7 & 7 & 8 \\
\hline 16 & 8 & 7 & 7 & 7 & 8 & 8 \\
\hline 17 & 7 & 7 & 7 & 8 & 8 & 8 \\
\hline 18 & 7 & 7 & 8 & 8 & 8 & 8 \\
\hline 19 & 7 & 8 & 8 & 8 & 8 & 8 \\
\hline
\end{tabular}

Berdasarkan tabel 3, data training yang digunakan diambil dari 2 tahun sebelumnya yaitu tahun 2017 dan 2018 dan dikelompokkan menjadi 2 yaitu data input dan data target. Data input adalah data penjualan dari bulan ke-1 sampai ke5 , sehingga data target menggunakan data bulan ke-6 selanjutnya untuk bulan ke- 2 hingga bulan ke- 6 digunakan sebagai data input dengan target bulan ke 7 dan begitu seterusnya. Hal yang sama juga dilakukan untuk data training kartu paket yang lain. Selanjutnya masuk kedalam tahap perhitungan menggunakan algoritma k-nn. Berikut adalah Langkah-langkah untuk menyelesaikan metode K-Nearest Neighbor:

a) Menentukan nilai $k$.

Penentuan nilai $k$ tidak memiliki aturan. Pada penelitian ini nilai $k$ yang digunakan adalah 2.

b) Menghitung jarak antara data training dan data testing yang ada pada tahap transformation menggunakan perhitungan Euclidean Distance sebagai berikut:

Kartu Paket SP1

$\mathrm{d} 1=\sqrt{(8-7)^{2}+(8-7)^{2}+(8-7)^{2}+(8-8)^{2}+(7-8)^{2}}=2$

$\mathrm{d} 2=\sqrt{(8-7)^{2}+(8-7)^{2}+(8-7)^{2}+(9-8)^{2}+(9-8)^{2}}=2,2360$ 


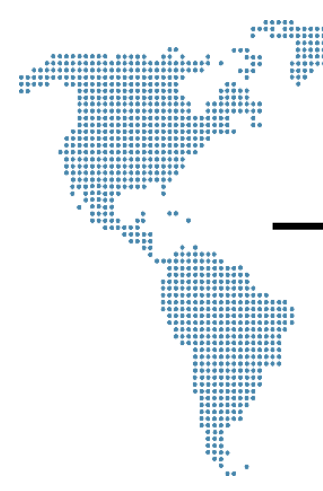

:14urnal Riset Sistem Informasi Dan Teknik Informatika (JURASIK) Volume 6 Nomor 1 Februari, pp 111-119 ISSN: 2527-5771/EISSN: 2549-7839 https://tunasbangsa.ac.id/ejurnal/index.php/jurasik

$\mathrm{d}_{3}=\sqrt{(8:-7)^{2}+(8-7)^{2}+(7-7)^{2}+(9-8)^{2}+(9-8)^{2}}=2$

$\mathrm{d} 4=\sqrt{(8-7)^{2}+(7-7)^{2}+(9-7)^{2}+(8-8)^{2}+(8-8)^{2}}=2,4494$

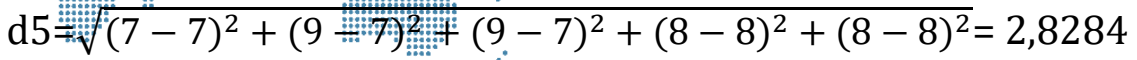

$\mathrm{d} 6=\sqrt{(9-7)^{2}+(9-7)^{2}+{ }^{2}(8-7)^{2}+(8-8)^{2}+(8-8)^{2}}=3$

$\mathrm{d} 7=\sqrt{(9-7)^{2}+(8-7)^{2}+(8-7)^{2}+(9-8)^{2}+(9-8)^{2}}=2,6457$

$\mathrm{d} 8=\sqrt{(8-7)^{2}+(8-7)^{2}+(8-7)^{2}+(9-8)^{2}+(9-8)^{2}}=2,2360$

$\mathrm{d} 9=\sqrt{(8-7)^{2}+(8-7)^{2}+(9-7)^{2}+(9-8)^{2}+(9-8)^{2}}=2,8284$

$\mathrm{d} 10=\sqrt{(8-7)^{2}+(9-7)^{2}+(9-7)^{2}+(9-8)^{2}+(9-8)^{2}}=3,3166$

$\mathrm{d} 11=\sqrt{(9-7)^{2}+(9-7)^{2}+(9-7)^{2}+(9-8)^{2}+(9-8)^{2}}=3,7416$

$\mathrm{d} 12=\sqrt{(9-7)^{2}+(9-7)^{2}+(9-7)^{2}+(7-8)^{2}+(7-8)^{2}}=3,7416$

Cara yang sama digunakan untuk mencari nilai dari kartu paket SP2, SP4, dan SP8.

c) Kemudian mengurutkan objek-objek tersebut ke dalam kelompok yang mempunyai jarak euclid terkecil.

D3=2, d19=2, d3=2,2360, d9=2,2360, d18=2,4494, d7 =2,6457, d4=2,8284, $\mathrm{d} 15=2,8284, \mathrm{~d} 17=3, \mathrm{~d} 6=3,3166, \mathrm{~d} 5=3,7416, \mathrm{~d} 10=3,7416$

d) Menentukan kelompok data hasil uji berdasarkan label mayoritas dari $k$ tetangga terdekat, dengan nilai $k=3$ maka diambil dua jarak terkecil yaitu d1, d2, dan d3.

e) Dengan menggunakan kategori Nearest Neighbor yang paling mayoritas maka dapat diprediksikan peningkatan jumlah penjualan pada priode berikutnya. Untuk penjualan kartu paket SP1 yaitu d1, d2, dan d3 (Januari, Februari, Maret), SP2 yaitu d5,d6, dan d7 (Mei, Juni, Juli), SP4 yaitu d10,d11, dan d12 (Oktober,November, Desember), dan SP8 yaitu d1,d2 dan d12 (Januari, Februari, Desember).

f) Accuracy dari perhitungan manual

Precision $=\frac{12}{12+3}=\frac{12}{15}=0,80=80 \%$

Recall $=\frac{12}{12+5}=\frac{12}{17}=0,70=70 \%$

Accuracy $=\frac{12+8}{12+8+3+5}=\frac{20}{28}=0,73428=71,43 \%$

Berdasarkan hasil akhir yang diperoleh, maka didapat alternatif $A_{1}$ dengan nilai $E_{k l}=1$, alternatif $A_{2}$ dengan nilai $E_{k l}=0$, alternatif $A_{3}$ dengan nilai $E_{k l}=3$, alternatif $A_{4}$ dengan nilai $E_{k l}=3$, alternatif $A_{5}$ dengan nilai $E_{k l}=0$. Sehingga masker wajah terbaik adalah GR dengan kode Alternatif $A_{4}$. Berikut adalah hasil penggujian data menggunakan system berbasis web.

Berdasarkan dari penjelasan diatas mengenai tahap-tahap penggunaan serta hasil yang telah ditampilkan maka selanjutnya membahas mengenai validasi data yang digunakan dengan tools rapidminer. Adapun hasil dari accuracy dari performance vextor sebesar 71,34\% dengan proses accuracy sebagai berikut: 


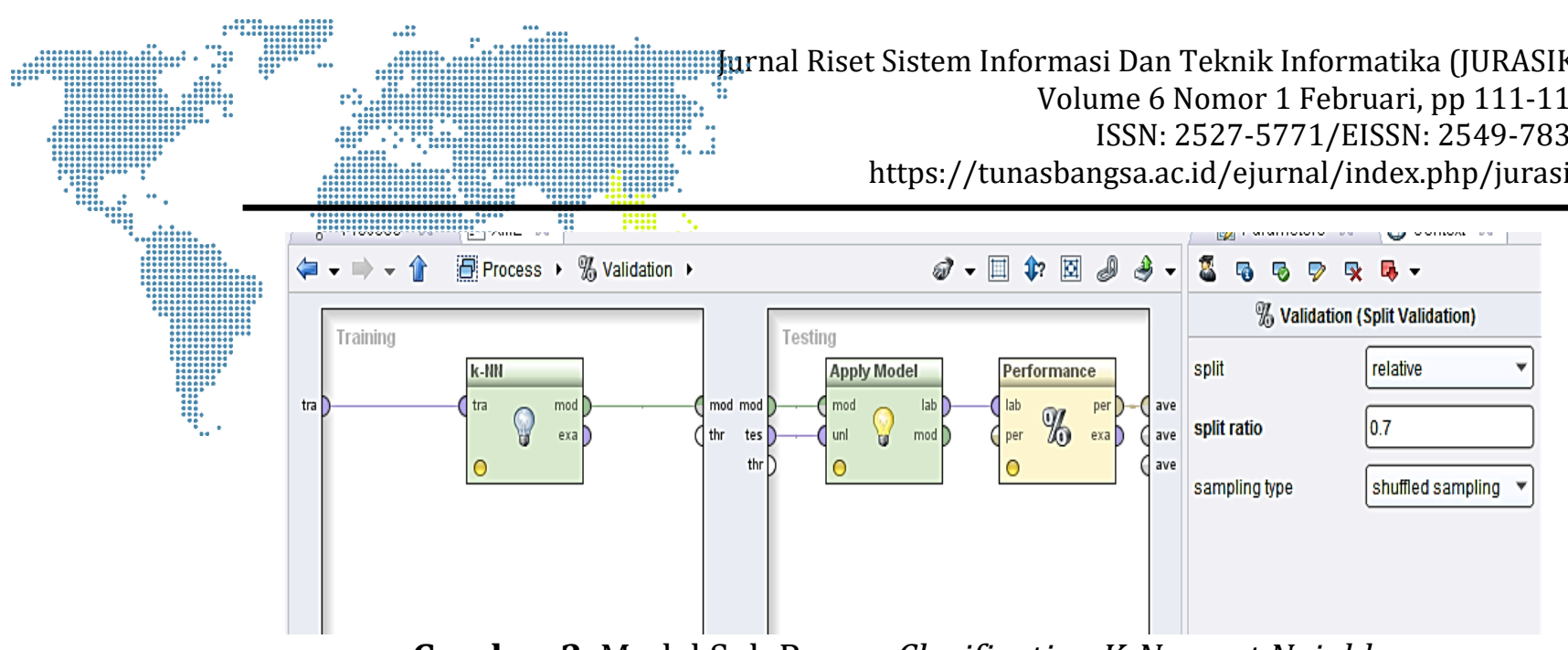

Gambar 3. Model Sub Proses Clasification K-Nearest Neighbor

Berikut adalah hasil accuracy dapat dilihat pada gambar 4.9:

\begin{tabular}{|c|c|c|c|c|c|}
\hline \multicolumn{5}{|c|}{ (-) Multiclass Classification Performance $\bigcirc$ Annotations } & (1) \\
\hline \multicolumn{6}{|c|}{ (-) Table View $\bigcirc$ Plot View } \\
\hline \multicolumn{6}{|c|}{ accuracy: $\mathbf{7 1 . 4 3 \%}$} \\
\hline & true SP 1 & true SP 2 & true SP 4 & true SP 8 & class precision \\
\hline pred. SP 1 & 2 & 2 & 0 & 0 & $50.00 \%$ \\
\hline pred. SP 2 & 1 & 2 & 1 & 0 & $50.00 \%$ \\
\hline pred.SP 4 & 0 & 0 & 3 & 0 & $100.00 \%$ \\
\hline pred. SP 8 & 0 & 0 & 0 & 3 & $100.00 \%$ \\
\hline class recall & $66.67 \%$ & $50.00 \%$ & $75.00 \%$ & $100.00 \%$ & \\
\hline
\end{tabular}

Keterangan :

Gambar 4. Hasil Accuracy

1. Jumlah prediksi produk SP1 dan kenyataannya benar produk SP1 adalah 2 record.

2. Jumlah prediksi produk SP1 dan kenyataannya benar produk SP2 adalah 2 record.

3. Jumlah prediksi produk SP2 dan kenyataannya benar produk SP2 adalah 2 record.

4. Jumlah prediksi produk SP2 dan kenyataannya benar produk SP4 adalah 1 record.

5. Jumlah prediksi produk SP2 dan kenyataannya benar produk SP1 adalah 1 record.

6. Jumlah prediksi produk SP4 dan kenyataannya benar produk SP4 adalah 3 record.

7. Jumlah prediksi produk SP8 dan kenyataannya benar produk SP8 adalah 3 record.

Berdasarkan gambar diatas, pemodelan yang telah di proses menggunakan tools rapidminer selain menghasilkan dalam bentu pola pemodelan ini juga dapat mengetahui keakuratan data. Berikut perbandingan dari perhitungan manual dan rapidminer.

Tabel 4. Perbandingan Hasil Manual dan Rapidminer

\begin{tabular}{|l|l|l|l|}
\hline No & Produk & Manual & Rapidminer \\
\hline 1 & SP 1 & $\begin{array}{l}\text { Januari } \\
\text { Februari }\end{array}$ & $\begin{array}{l}\text { Januari } \\
\text { Maret }\end{array}$ \\
\hline
\end{tabular}




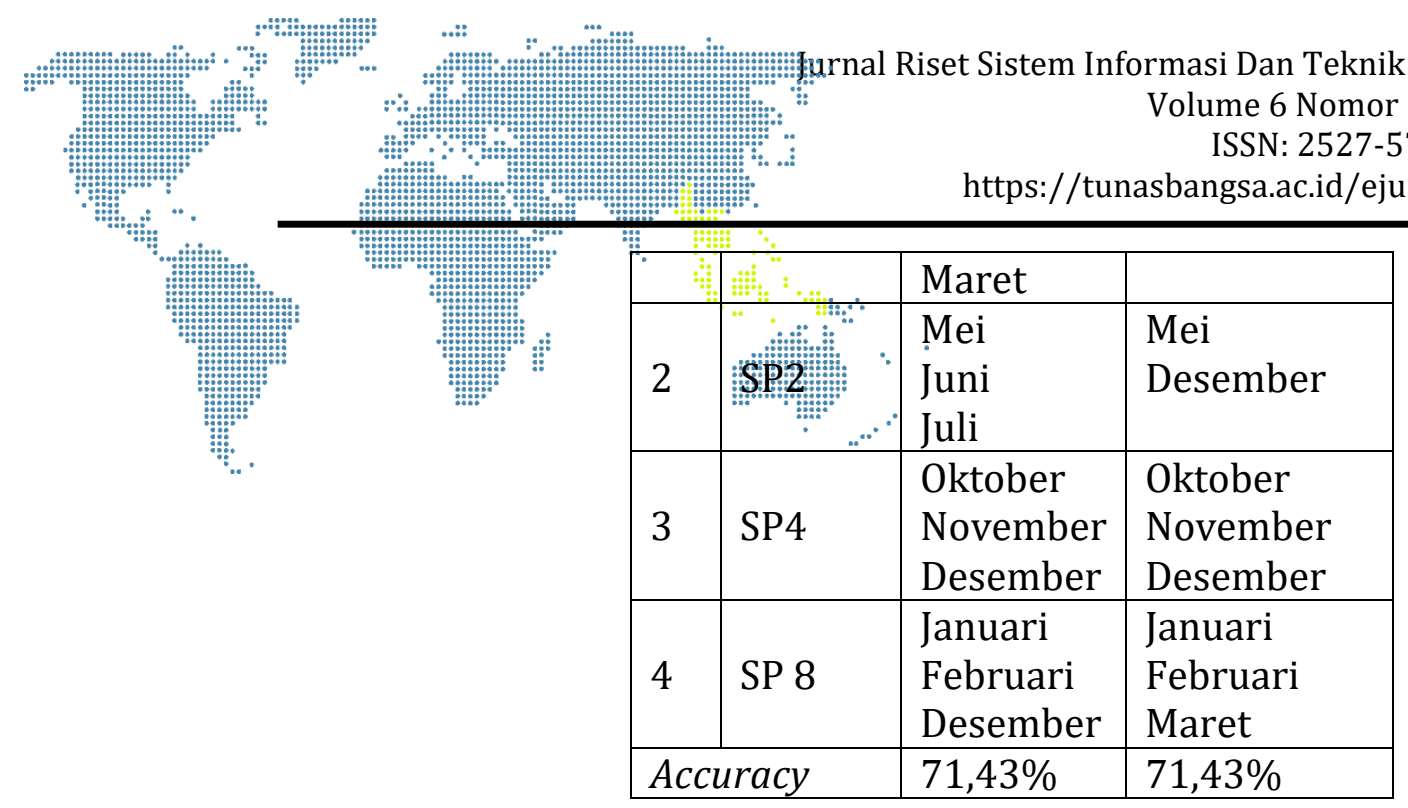

Accuracy data yang didapat sebesar $71,43 \%$ dengan menggunakan tools rapidminer. Secara manual accuracy yang diperoleh sebesar 71,43\%.

\section{SIMPULAN}

Pada penelitian ini dilakukan pemodelan menggunakan algoritma $k$-nearest neighbor dengan menggunakan data yang diolah berdasarkan tahapan knowladge discovery in database (KDD). Berdasarkan hasil perhitungan data mining menggunakan teknik klasifikasi dan algoritma k-nearest neighbor, didapatkan hasil prediksi penjualan kartu paket kuota internet dengan 4 jenis paket internet dan data yang digunakan pada tahun 2017 - 2019 yang dimana atribut terdiri dari Nama Produk, Kuant, dan Bulan kemudian berdasarkan nilai akurasi terhadap prediksi penjualan produk untuk tahun 2020 yaitu sebesar 71,43\% dan telah diuji menggunakan tools Rapid Miner . 5.0.

\section{DAFTAR PUSTAKA}

[1] T. R. Vulandari, "Tahapan Data Mining," In Data Mining, Teori Dan Aplikasi Rapirminer, 2017.

[2] D. N. Batubara And A. P. Windarto, "Analisa Klasifikasi Data Mining Pada Tingkat Kepuasan Pengunjung Taman Hewan Pematang Siantar Dengan Algoritma," Komik (Konferensi Nas. Teknol. Inf. Dan Komputer), Vol. 3, No. 1, Pp. 588-592, 2019, Doi: 10.30865/Komik.V3i1.1664.

[3] A. Muzakir And R. A. Wulandari, "Model Data Mining Sebagai Prediksi Penyakit Hipertensi Kehamilan Dengan Teknik Decision Tree," Sci. J. Informatics, Vol. 3, No. 1, Pp. 19-26, 2016, Doi: 10.15294/Sji.V3i1.4610.

[4] Hasmawati, Nangi, Jumadil, And M. Muchtar, "Aplikasi Prediksi Penjualan Barang Menggunakan Metode K-Nearest Neighbor (Knn) (Studi Kasus Tumaka Mart)," Semantik, Vol. 3, No. 2, Pp. 151-160, 2017.

[5] N. N. Dzikrulloh And B. D. Setiawan, "Penerapan Metode K - Nearest Neighbor ( Knn ) Dan Metode Weighted Product ( Wp ) Dalam Penerimaan Calon Guru Dan Karyawan Tata Usaha Baru Berwawasan Teknologi ( Studi Kasus: Sekolah Menengah Kejuruan Muhammadiyah 2 Kediri )," Vol. 1, No. 5, Pp. 378-385, 2017.

[6] M. Faid, M. Jasri, And T. Rahmawati, "Perbandingan Kinerja Tool Data Mining Weka Dan Rapidminer Dalam Algoritma Klasifikasi," Teknika, 2019, Doi: 10.34148/Teknika.V8i1.95. 